\title{
Effect of storage period atcold storage on some physical and chemical properties of + potato tuber prepared for processing
}

\author{
Rabya A Lahmer \\ Faculty of Agriculture, Department of Food science and Technology, Tripoli University, Libya. \\ Email: rabyalahmer@yahoo.co.uk
}

\begin{abstract}
The aim of this study was to evaluate the effect of storage period and condition on the physical and chemical properties of potato tuber prepared for processing. Two varieties of potatoes namely Diamant and Santana were evaluated for their suitability for industrial production of chips and French fries with respect to storage period. The quality characteristics of the potato samples were examined during cold storage at $10^{\circ} \mathrm{C}$ and $75-85 \%$ relative humidity and treated with (ChlorphenylIso- Propyl- N-3-Carbamate CIPC) as sprout inhibitor. Physical properties of potatoes were evaluated every 2 months for 6 months throughout 2 seasons. The results obtained showed that there was relative increase on dry matter content ranged between $21.70 \%$ at zero time to $23.73 \%$ at six months for Diamant variety and $21.53 \%$ at zero time to $25.80 \%$ at six months for Santana variety at both seasons. Also there was observed increase in specific gravity from 1.092 at zero time to 1.097 at six months for Diamant variety and 1.086 at zero time to 1.107 at six months for Santana variety at both seasons. For chemical parameters tested there was a decline in starch content $19.51 \%$ at zero time to $15.45 \%$ at six months and $19.55 \%$ at zero time to $16.70 \%$ at six months for Diamant and Santana varieties respectively.. For chemical parameters tested there was a decline in starch content $19.51 \%$ at zero time to $15.45 \%$ at six months and $19.55 \%$ at zero time to $16.70 \%$ at six months for Diamant and Santana varieties respectively. Accordingly there was an increase in reducing sugars from $0.234 \%$ at zero time to $0.278 \%$ at six months and from $0.233 \%$ at zero time to $0.266 \%$ at six months for Diamant and Santana varieties, respectively, which affected both quality and consumer acceptability due tononenzymatic browning result in darkening of chips and French fries colour. The main recommendations of this study are that the storage condition must be controlled during storage period due to its critical effect on the quality characteristics of potato frying products.
\end{abstract}

Keywords: Cold storage, Potato, Reducing sugars, Starch, storage period.

\section{Introduction}

Potato, Solanumtuberosum is an annual dicot species belonging to family Solanaceae. Cultivated potato originated in the high lands of South America, where it has been cultivated for more than 800 years (Anon., 2004).Potatoes are grown in about 125 countries throughout the world (Anon, 2004). The production of potatoes is about 316 million metric tons each year, making it the fourth leading food crop after wheat, rice and corn (Anon, 2004). Furthermore, production of potatoes is increasing, particularly in developing countries. Average yield is about $16 \mathrm{t} / \mathrm{ha}$. Presently China is the world leader in potato production and USA comes in the fourth division (Anon, 2004). From nutritional point of view, the potato available food crop, especially in countries where the diet is unbalanced, the addition of potatoes products will considerably improve the nutritional value of the food products. It is estimated that $100 \mathrm{~g}$ of potatoes provide $8 \%$ of the daily minimum requirement of protein, $10 \% \mathrm{Fe}, 20-25 \%$ vitamin $\mathrm{C}$, $10 \%$ vitamin $\mathrm{B}$, and about $3 \%$ of the daily energy requirements. Moreover, from the production side, in many parts of the world, including tropical and subtropical regions, the potato can compete with the main food crops, both as source of energy (Calories) as well as high protein for the lower class people per day (Beukema and Zaag 1979).
Potato processing is almost old as the potato itself, In market study for potato chips in Sudan, Yousif (2007) found that there exists no commercially operating potato chips industry in Sudan. He also found that most potato chips in the markets are imported from Saudi Arabia and Egypt. The amount of potato chips imported is in increase from year 2002, amounting from 275 tons to 772 tons in year 2006. The potato chips market is expanding and projected to increase to round 1138 tons by year 2016 (projection analysis). The proposed potato chips should adopt direct distribution to retail market; this together with the importer profile should make the local production more competitive.

\section{Materials and Methods}

The two varieties of potatoes (Diamant and Santana) were obtained from Omer Khalifa cold storage rooms (Omdurman). Fifty $\mathrm{kg}$ of each sample were used every season. The two varieties were evaluated for Effect of storage period and condition on physical properties. Tubers were treated with ChlorphenylIso- Propyl- N-3-Carbamate (CIPC) $2 \mathrm{~kg} /$ ton to control sprouting. Then potato tubers were stored in cold storage $\left(10^{\circ} \mathrm{C}\right)$ for six months, the sampling was repeated every two months for 2 seasons.

\section{Physical analysis}




\section{Specific gravity and dry matter content}

Specific gravity and dry matter content were determined using potato hydrometer. (APH group 2003).

A random $3660 \mathrm{~g}$ of potatoes were weighed in wire basket. Potatoes were dry and free from dirt. If necessary cut one of the potatoes in order to obtain the exact weight. The potatoes and the basket were held; attach the hook of the bulb in to the wire loop in the center of the basket, and bulb in thirty gallon container of water. Readings of specific gravity or percent dry matter wastaken as soon as the hydrometer comes to rest while floating in the water. The higher the reading the more potatoes are for chipping. Good quality potatoes should have a specific gravity of 1.080 . Potatoes with specific gravity less than 1.070 are unacceptable (the hydrometer should read 1.070 at water level).

\section{Chemical analysis}

\section{Reducing sugars}

Determination of reducing sugars is carried out according to Dinitrophenol Method, which is a modification of colorimetric method of Ross (1959). The potato was first dried in drying oven at $50{ }^{\circ} \mathrm{C}$ overnight then minced to prepare powder. Reducing sugars were extracted using distilled water; the extract then reacts with dinitrophenol solution. The generated colour was measured at $600 \mathrm{~nm}$ for determination of reducing sugars content (Long and Chism, 1987).

One gram of homogenized powder sample was washed with $5 \mathrm{ml}$ of distilled water into a $50 \mathrm{ml}$ conical centrifuge tuber, vortexed for 45 seconds, and centrifuged at $200 \mathrm{rpm}$ for $10 \mathrm{~min}$. The supernatant was used to determine total reducing sugars.

$1.0 \mathrm{ml}$ of potato supernatant was pipetted into a 16 $\mathrm{cm}$ test tube. $2.0 \mathrm{ml}$ of dinitrophenol solution was added to each tube, mixed thoroughly (Vortexed 10 seconds) and then was heated in boiling water for 6 min. and cooled for $3 \mathrm{~min}$ in a cool water6 ${ }^{\circ} \mathrm{C}$. Kept cold at the same temperature $\left(6^{\circ} \mathrm{C}\right)$ and was read at $600 \mathrm{~nm}$ before $20 \mathrm{~min}$ elapse. Sample was read in a cell of $1.0 \mathrm{~cm}$ path length in a Gilford spectrophotometer. The meter was first set at zero for distilled water. The calibration curve was prepared each time byusing standard anhydrous glucose solution. $1 \mathrm{ml}$ of serial standard glucose solutions with concentrations of $0.2,0.5$ and $1.0 \mathrm{ml}$ were treated respectively exactly as were the potato samples. A linear regression equation was generated using a Hewlett Packard Model 10 calculator with standards and this equation was used to determine the reducing sugar content in samples (Long and Chism, 1987).

\section{Starch content}

Three $\mathrm{ml}$ of the filtered starch solution was diluted to $50 \mathrm{ml}$. the filtrated starch solution was pipetted into borosilicate glass tube, cooled inwater (at $6^{\circ} \mathrm{c}$ ) and 10 $\mathrm{ml}$ of fresh Anthrone reagent was added, mixed well then heated for $6 \mathrm{~min}$ at $100^{\circ} \mathrm{C}$. The tube was cooled rapidly to $6^{\circ} \mathrm{c}$ in water bath and the color was determined using wave length $600 \mathrm{~nm}$.Standard curve of pure glucose $0.2,0.5$ and $1.0 \mathrm{ml}$ was prepared to obtain the yield of glucose from starch. Glucose was multiplied by 0.90 to convert to starch (McCready 1950).

Data generated was subjected to Statistical Analysis System (SAS) using One- Variable Analysis of Variance (ANOVA), and then mean separation done by Duncans Multiple Range Test (DMRT) referred to by Mead and Gurnow (1983).

\section{Results and discussion}

The results concerning specific gravity of the investigated samples were illustrated in Table (1). Data indicated that there was an increase in specific gravity during the storage period of six months, throughout the two seasons. It had been observed that both varieties lost water and shrinkage, especially the variety Santana after 6 months of storage during the first season.

However, Sasaki (2004) found that there was a significant difference in specific gravity during storage time (6 months) and accordingly the specific gravity ranged between 1.080 and 1.120. Yousif (2007) found that in study of eleven potato cultivars grown in Khartoum State, Sudan, the specific gravity ranged from 1.080 to 1.102 . Cheong and Govinden (1998) found that the specific gravity of two processing potato varieties ranged between 1.078 at zero time of storage and 1.087 after 12 weeks of storage.

It is of interest to mention that specific gravity of potato tuber is an important measure of quality that was used extensively by processors to assess the suitability for the production of chips and French fries. Jeffrey, et al (2004) found that there were many factors influencing the specific gravity. Air and soil temperature are the primary environmental factors affecting specific gravity. Warm day and cool nights provide optimal conditions for producing high specific gravity tubers. High soil temperature has a direct effect on tuber physiology and inhibits starch deposition.

Other factors also may influence specific gravity such as variety, seed management and nutrients management. However, applying excessive amount of nitrogen andpotassium can decrease specific gravity. Excessive nitrogen rates stimulate vine and root growth and delay tuber bulking and maturation, and high potassium concentration decrease specific gravity as tubers began to absorb more water due to osmotic effect of increased tissue salt concentration. Generally, any event or condition that destroys foliage or shortens the growing season can influence tuber specific gravity (Jeffrey, et al 2004). Wilston and Andrea (2008) found that the specific gravity of a tuber depends not only on the percentage of dry matter 
in it but also on the density of the dry matter and the percentage of air in the tissue.

\section{Effect of storage period on dry matter content of potato tubers:}

Dry matter content of the investigated samples as a function of storage period for six months was demonstrated in Table (2). Data obtained indicated that the dry matter increased from 21.70 to $23.73 \%$ for Diamant variety during the first season (2007) and from 22.30 to $23.23 \%$ during the second season (2008). The same trend was observed for Santana variety during the first season 21.53 to $25.80 \%$ and from 21.33 to $23.87 \%$ in the second season.

The obtained results in this study concerning dry matter content were in general agreement with the published results. Beukema and Zagg (1979) reported that that there were many factors influencing dry matter content of potato tubers; namely: variety, maturity, growth pattern (nitrogen fertilizer), climate and soil and potassium fertilizer application. The varieties which mature early usually have lower dry matter content than later varieties. Also dry matter content increased with the progress of the growing season and the growing season greatly influenced the degree of maturity obtained.

In Dutch conditions, the highest dry matter content was obtained from silt soil, while sandy soil gave the lowest content. This was related to the availability of water for plant (Burton 2006). It has been reported that potassium has a very important effect on dry matter content which was inversely proportional to the potassium content of the soil (Beukema and Zagg 1979).

A significant variation in the dry matter content (19.3-23.3\%) of Indian potato varieties were reported by Marwaha, et al (2009) he also reported that potato tubers with high dry matter content were considered suitable for chips production. Moreover, Agilera and Gloria (1997) reported that the dry matter content was associated with mealiness, crispness and reduced oil uptake in the fried chips. It has been reported that the dry matter content of eleven potato varieties ranged between $17.7 \quad-24.6 \%$ (Illeperuma and Wickramasingfhe, 2000). As well, APH group manual of potato hydrometer reported that the potato varieties dry matter content ranged between 17.07- 25.49\%. On the other hand, eleven potato cultivars from Dutch origin were tested for their chips performance in Sudan in 2006-2007. The tests were part of an EVD PESP (Netherlands) funded study focused on the feasibility to establish a new potato processing chain in Sudan. The results obtained indicated that the dry matter content of those cultivars ranged between $20.17-24.63 \%$. Therefore, it could be concluded that the results obtained in this study were within the published values. Mohamed (1984) in a study of three potato cultivars tested under central Sudan conditions found that the dry matter content of these cultivars ranged between 16.2 to $21.4 \%$. However, Marwaha
(2009) reported that the dry matter content of three potato processing cultivars was ranging from 17.3 up to $24.1 \%$.

From processing point of view Harries (1978) reported that the product yield was greater per unit fresh weight from tuber with a higher solid content. Moreover, it has been reported that the potatoes with high dry matter content was considered suitable for chips production, so Diamant variety was more suitable for this process (Halliburton and Muir 2008).

\section{Effect of storage period on starch and reducing Sugars content of potato tubers}

The effect of storage period on starch and reducing sugars content of potato tubers in the second season was shown inTable (3). Data indicated that starch content decreased during storage period of six months from 19.51 to $15.45 \%$ for Diamant variety and 19.55 to $18.21 \%$ for Santana. The reduction in starch content of both Diamant and Santana varieties, observed in this study, was mainly due the breakdown of starch as a function of storage.

On the other hand, reducing sugars content for the two varieties (Diamant and Santana) increased, which was mainly due to the breakdown of the starch. Such findings were probably due to mechanical disorder of the cooling system,led to increase in temperature directly observed in decrease of starch content and increase in reducing sugar content. Cheong and Govinden (1998) found that the reducing sugars of two processing potato cultivars ranged between 0.24 and $0.37 \%$. It has been reported that the storage condition employed intended to minimize reducing sugars accumulation in order to favor light colored fries (Mosley, 2001). However, Alnaem (2004) concluded that the success of storing potatoes depends on thefollowing parameters; quality of the harvested tubers, storability of the variety and possibility to regulate temperature and humidity.

Sasaki, et al (2004) found that there was a considerably greater amount of reducing sugars in potato tubers stored at $6^{\circ} \mathrm{C}$ for 6 months, though, a considerable decrease in reducing sugars was reported after reconditioning for 30 days. Moreover, it is of interest to mention that almost $80 \%$ reducing sugars reverse to starch and the remaining $20 \%$ used in respiration process as stated by Sasaki, et al (2004). However, Haverkortet al (2002) found that the requirements with regard to the content of reducing sugars depend on the end productof all processing industries, the crisps industry makes the highest demands on the content of reducing sugars; the reducing sugar content must not exceed $0.2-0.3 \%$ for the French fries industry. Rastovski and Estelal (1981) reported that during storage of potato tubers the conversion of starch into reducing sugars was greatly affected by temperature. Since long ago, it has been reported that the upper limits of reducing sugar content to produce an acceptable colour for fried products such as French fries and chips were 0.25 and 
$0.5 \mathrm{mg} / \mathrm{g}$; respectively. The average reducing sugar content of potato tubers was found to be $0.55 \%$. In the same context they also reported that a proximate range of reducing sugars content in potato tubers from 0.25 to $0.3 \%$. Pritchard (1993) reported that water hydrolysis or breakdown of sucrose in harvested tubers result in production of reducing sugars (glucose and fructose). As well, stress such as low temperature, low oxygen, or physiological damage usually endedup with increasing in reducing sugars. It has been found that small potato tubers are higher in sugars than big tubers. Jeffrey et al (2004) stated that reducing sugars (both glucose and fructose) were created the most serious problem during frying because they are chemically reactive. The previous Authors (Jeffrey et al 2004) also found that there weremany other factors influencing tuber sugars such as tuber maturity, temperature, both in field and in storage, has a large impact on tuber sugar content, variety, storage stress and handling. It has been recommended that potato intended for chips production should have a reducing sugar level below $0.035 \%$ on fresh tuber weight. However, potato intended for French fries processing should have less than $0.12 \%$ reducing sugar level on fresh weight. Potato tubers with higher values than these will usually show colour problems after frying. Yousif (2007) found that the reducing sugar ranged between 0.0461 and $0.330 \%$ were suitable for potato chips production.

Table 1. Effect of storage period on specific gravity of Diamant and Santana potato varieties for 2 seasons

\begin{tabular}{ccccc}
\hline $\begin{array}{c}\text { Storage period } \\
\text { per months }\end{array}$ & \multicolumn{2}{c}{$\begin{array}{c}\text { Specific gravity } \\
\mathbf{1}^{\text {st }} \text { season }\end{array}$} & \multicolumn{2}{c}{$\begin{array}{c}\text { Specific gravity } \\
\mathbf{2}^{\text {nd }} \text { season }\end{array}$} \\
\cline { 2 - 5 } & Diamant & Santana & Diamant & Santana \\
\hline 0 & $1.092 \pm 0.00^{\mathrm{d}}$ & $1.086 \pm 0.00^{\mathrm{d}}$ & $1.090 \pm 0.00^{\mathrm{d}}$ & $1.085 \pm 0.00^{\mathrm{a}}$ \\
\hline 2 & $1.094 \pm 0.01^{\mathrm{c}}$ & $1.093 \pm 0.00^{\mathrm{c}}$ & $1.092 \pm 0.00^{\mathrm{c}}$ & $1.078 \pm 0.00^{\mathrm{d}}$ \\
\hline 4 & $1.095 \pm 0.00^{\mathrm{b}}$ & $1.095 \pm 0.00^{\mathrm{b}}$ & $1.095 \pm 0.00^{\mathrm{b}}$ & $1.079 \pm 0.00^{\mathrm{c}}$ \\
\hline 6 & $1.097 \pm 0.00^{\mathrm{a}}$ & $1.107 \pm 0.00^{\mathrm{a}}$ & $1.094 \pm 0.00^{\mathrm{a}}$ & $1.080 \pm 0.00^{\mathrm{b}}$ \\
\hline LSD $_{0.05}$ & $0.0005954^{* *}$ & $0.0005954^{* *}$ & $0.0005954^{*}$ & $0.0005954^{*}$
\end{tabular}

Mean \pm SD bearing different superscript letters in a column are significantly different at $(\mathrm{P}<0.05)$.

Storage condition: Temperature: $10^{\circ} \mathrm{C}$, Relative humidity: $75-85 \%$.

Table 2. Effect of storage period on dry matter content of Diamant and Santana potato varieties 2 seasons (2007-2008)

\begin{tabular}{|c|c|c|c|c|}
\hline \multirow{2}{*}{ Storage period* } & \multicolumn{2}{|c|}{$\begin{array}{c}\text { Dry Matter Content } \\
1^{\text {st }} \text { season }\end{array}$} & \multicolumn{2}{|c|}{$\begin{array}{c}\text { Dry Matter Content } \\
2^{\text {nd }} \text { season }\end{array}$} \\
\hline & Diamant & Santana & Diamant & Santana \\
\hline 0 & $21.700 \pm 0.62^{\mathrm{a}}$ & $21.533 \pm 0.68^{c}$ & $22.30 \pm 0.35^{\mathrm{b}}$ & $21.33 \pm 0.38^{c}$ \\
\hline 2 & $22.700 \pm 0.61^{\mathrm{a}}$ & $23.300 \pm 0.15^{\mathrm{b}}$ & $22.73 \pm 0.64^{\mathrm{ab}}$ & $22.56 \pm 0.12^{\mathrm{b}}$ \\
\hline 4 & $23.000 \pm 0.61^{\mathrm{a}}$ & $23.400 \pm 0.10^{b}$ & $23.13 \pm 0.12^{\mathrm{a}}$ & $23.20 \pm 0.10^{a}$ \\
\hline 6 & $23.733 \pm 0.30^{\mathrm{a}}$ & $25.800 \pm 0.30^{\mathrm{a}}$ & $23.23 \pm 0.06^{\mathrm{a}}$ & $23.87 \pm 0.23^{\mathrm{a}}$ \\
\hline $\operatorname{LSD}_{0.05}$ & $1.271^{\mathrm{n} . \mathrm{s}}$ & $1.295^{* *}$ & $0.6994^{*}$ & $0.6310^{* *}$ \\
\hline
\end{tabular}

Mean \pm SD bearing different superscript letters in a column are significantly different at $(\mathrm{P}<0.05)$

*Per months 
Table 3. Effect of storage period on starch and reducing sugars content of Diamant and Santana potato varieties $\left(2^{\text {nd }}\right.$ season $)$

\begin{tabular}{|c|c|c|c|c|}
\hline \multirow{2}{*}{$\begin{array}{l}\text { Storage } \\
\text { Period* }\end{array}$} & \multicolumn{2}{|c|}{ Starch \% } & \multicolumn{2}{|c|}{ Reducing sugars \% } \\
\hline & Diamant & Santana & Diamant & Santana \\
\hline 0 & $19.51 \pm 0.32^{\mathrm{a}}$ & $19.55 \pm 0.17^{\mathrm{a}}$ & $0.234 \pm 0.00^{\mathrm{d}}$ & $0.233 \pm 0.00^{\mathrm{d}}$ \\
\hline 2 & $18.56 \pm 0.46^{\mathrm{b}}$ & $18.21 \pm 0.43^{b}$ & $0.246 \pm 0.00^{\mathrm{c}}$ & $0.239 \pm 0.01^{\mathrm{c}}$ \\
\hline 4 & $17.55 \pm 0.14^{\mathrm{c}}$ & $17.88 \pm 0.49^{\mathrm{b}}$ & $0.257 \pm 0.00^{\mathrm{b}}$ & $0.250 \pm 0.01^{\mathrm{b}}$ \\
\hline 6 & $15.45 \pm 0.25^{\mathrm{d}}$ & $16.70 \pm 0.26^{\mathrm{c}}$ & $0.278 \pm 0.00^{\mathrm{a}}$ & $0.266 \pm 0.01^{\mathrm{a}}$ \\
\hline Lsd 0.05 & $0.5945^{* *}$ & $0.6867^{* * *}$ & $0.0005954^{* *}$ & $0.0005954^{*}$ \\
\hline
\end{tabular}

Mean \pm SD bearing different superscript letters in a column are significantly different at $(\mathrm{P}<0.05)$ Per months

\section{References}

Agilera, J. M. and Gloria, H. (1997). Oil absorption during frying of frozen par fried potatoes - food engineering and physical properties.

Alneam, N. S. (2004) The problem of potato storage in Khartoum state. A thesis of M. Sc Khartoum University,Sudan.

Anon, (2004) Potato -Oregon State University (OSU). The Valley Library Corvallis, OR 97331-4504.

APH Group (2003). Potato Hydrometer Information and Instructions- Agricultural Production \& Handling PO. Box 30, 8500 AA Joure Holland.

Beukema, H. P. and Zagg, V. D. (1979). Potato Improvement - some factors and factsInternational Agriculural Center, Washingen, USA.

Burton, G.W. (2006) The Sugar Balance in Some British Potato Varieties during Storage- EUR Potato Journal, 8:80-91.

Cheong, J. K. C. and Govinden, N. (1998). Quality Of Potato During Storage At Three Temperature - Mauritius Sugar Industry Research Institute www.gov.mu/portal/sites/ncb/moa/farc/...

Halliburton, R.and Muir, J. (2008) London's best Chips, Time out London: 2, http://timout.com/London/restaurants/feat ures/3254/2.html

Harries, P. M. (1978) The Potato crop (Chapman and Hall, London,UK), page 512-522.

Haverkort, A.J. Loon, C.D. Eijck, P. , Scheer, F.P, Peeten, H.M.G. Baarveld, H.R.,Campobello, E.W.A and Liefrink, S.R. (2002). On the Road to Potato Processing. Publisher NIVAA The Netherlands Consultative Potato Institute, Den Haag, The Netherlands.

Illeperuma, D.C.K. andWickramasingfhe, N.K. (2000). Sutibility of Locally Available Potato Varieties for Chipping - University of Peradeniya, Peradeniya,USA.

Jeefrey C. Stark, N.O., Gale E. K and Stephan L. L. (2004) Tuber Quality.

Long, A.R. and Chism, G.W. (1987). Dinitrophenol method for determination of total reducing sugars in potato tubers. Journal of Food Science and Technology 52:150-154.
Marwaha R.S.SinghS.V,PandeyS.K and Kumar V.K. (2009). Evaluation of advanced potato hybrid MP/97-644 and processing varieties for yield and chipping quality in north-eastern hills .Indian Journal of Horticulture, 363-366

McCready, R. M.; Jack. G., Vernon and Owens, H. S. (1950). Determination of Starch and Amylose in Vegetables. Anal. Chem., 22 (9): 1156-1158

Mead, B.andGurnow, R. W. (1983). Statistical Methods in Agricultural Experimental Biology,New York, USA. Chapman and Hall

Mohammed, A. I. (1984). Dry matter content, protein content, and yield of potato as affected by cultivers and planting date in Sudan - M.SC thesis Faculty of Agriculture Khartoum University,Sudan.

Mosely, A.R. (2001). Manufacture, Storage and Transport of Frozen French Fries.

Pritchard, M.K. (1993) Relationships of Sugars to color of processed Potatoes - University of Manitoba (report).

Rastovski, A. and Estelal, A. (1981). Storage of Potatoes (Post-harvest, Behaviour, Store design Storage practice, Handling ) center of Agricultural Publishing \& Documentation Wageningen. USA.

Ross, A. F. (1959) Dinitrophenol method for reducing sugars. The Avi. Publishing company, First edition ,Wesport.

Sasaki, T. D., Perez, K., and Himoto, J. I. (2004) . Effect of Reconditioning on the Quality of Different processing Potato Cultivars after Low Temperature Storage - Food Preservation Science 30, 3.

Wilston, J. H.; and Andrea M. L. (2008). The relation between specific gravity and dry matter content of potato tubers. American Journal of Potato researches, volume 46.

Yousif, K. S. (2007). Evaluation of potato cultivars for chip making - cited in Development of a new potato chain in Sudan edited by Wastman, R.; Meijer, B. J. M. Applied plant research. Wageningen,USA . 
